\title{
Table of Miniatures in Selected Texts by Machaut, MSS Bibl. Nat. fr. 1584 and $15^{86}$
}

No comprehensive study of the illumination of Machaut manuscripts has been published. To my knowledge the only such study is the doctoral dissertation of Kumiko Maekawa, "Recherches iconographiques sur les manuscrits des poésies de Guillaume de Machaut: Les Décorations des premiers recueils personnels." A concordance of miniatures appears in Lawrence Earp's dissertation, "Scribal Practice, Manuscript Production and the Transmission of Music in Late Medieval France: The Manuscripts of Guillaume de Machaut."

Bibl. Nat. fr. $15^{86}$

Remede de Fortune

Line

I L'Amant, accompanied by his valet, stands to one side and watches his lady; she stands, with three attendants, in front of her castle, and points at him. The lady wears a pink hat, which she wears in every miniature except one (fol. $5^{6 \mathrm{v}}$ ).

135 L'Amant talks to the God of Love.

$43^{1} \quad$ L'Amant sits among trees, writing on a long scroll (lay).

693 L'Amant, outdoors, reads lay from a long scroll to his lady. People seated on the ground in the background.

921 Top: L'Amant, looking woebegone, writes musical notes on a scroll in a walled garden.

Bottom: Fortune and her wheel (complainte).

Folio

Nebuchadnezzar asleep in bed; statue with gold head, black

1001 Nebuchadnezzar asleep in bed; statue
torso, and brown feet in background. 


\section{Appendix B}

1273 L'Amant watches his lady disappear, with attendants, into her castle.

1401 L'Amant sits on the ground, looking miserable.

1481 Hope, wearing her fluttering scarf, holds l'Amant's hand; he appears to sleep. (Hope always wears this scarf.)

1671 Hope addresses l'Amant.

1821 Hope addresses l'Amant.

1881 L'Amant and Hope sit on either side of a tree, from which hangs a blue shield, decorated with a red heart pierced by an arrow and white tear drops.

1997 Hope sings from a scroll; l'Amant sleeps (chanson royal).

2039 Hope places a ring on l'Amant's finger.

2148 Hope addresses l'Amant.

2287 L'Amant addresses Hope.

2353 L'Amant bows to Hope.

2403 Hope addresses l'Amant.

2522 L'Amant addresses Hope.

3181 With Hope in the distance, l'Amant writes on a scroll (prière).

$345^{1}$ Carol (circle dance) under trees, near fountain, beside castle. L'Amant, standing next to his lady, sings; three more people watch from the side (virelay).

3573 L'Amant and his lady talk outside castle, surrounded by other couples.

3729 L'Amant and his lady talk privately, accompanied only by her attendant.

3847 L'Amant kneels before his lady while other ladies watch.

3947 Banquet scene. L'Amant, sporting a pink hat like his lady's, looks at her from across the room.

4077 As Hope watches over them, l'Amant and his lady exchange rings.

4107 At the scene of a tournament, l'Amant, scroll in hand, rides off, looking back toward the audience of ladies. None wears a pink hat (rondeau).

4217 L'Amant and his lady talk.

\section{Lays}

Lady, wearing fluttering scarf, gestures toward man, who sits on the ground and writes on a scroll ("Loyauté que point ne delay").

Man stands amid flowers ("J'aim la flour").

Man, seated on ground, writes on scroll ("Pour ce qu'on puist miex retraire"). 
Man, holding long scroll, stands before audience of men and ladies ("Aus amans pour exemplaire").

Man stands next to flowering tree ("Nuls ne doit avoir merveille").

Man stands amid flowers and points toward text ("Par trois raisons me vueil deffendre").

Man stands beside flowering tree ("Amour doucement me tente").

Lady stands amid flowers ("Amis t'amour me constraint").

Man looks at bush as if startled; a face peers out from it ("Un mortel lay vueil commencier").

Man and lady converse ("Qui bien aimme à tart oublie").

Lady amid flowers in miniature; in opposite margin, a man holding a blue flower points at her ("Ne say comment commencier").

Man holding blue flower in miniature; in opposite margin, a lady points at him ("Se quanque Diex en monde a fait").

A man addresses an audience of four ladies and a man ("Maintes foys oy recorder").

Man, seated on ground, writes on scroll; lady watches from nearby castle tower ("On parle de richesses et de grant signorie").

Lady addresses three other ladies ("Amour se plus demandoie").

Bibl. Nat. fr. 1584

\section{Remede de Fortune}

Blue shield bearing a red heart, pierced by an arrow, hangs

Hope places a ring on l'Amant's finger; he appears to sleep.

Fonteinne amoureuse: Prologue and "Complainte a l'amant" 


\section{Appendix B}

55 Narrator (tonsured) asleep in bed.

235 Narrator writes while l'Amant speaks in a different room. $\quad 155 \mathrm{~V}$

539 L'Amant sits with clasped hands, bowed head. $157 \mathrm{~V}$

571 Ceyx drowned; Alcyone prays to Juno. 157v

587 Iris hovering over Juno, who lies in bed. $\quad 15^{8}$

603 Iris hovering over god of sleep, who sleeps in bed. $\quad 158$

619 God of sleep, or Morpheus, sits sleepily on bed. $\quad 158$

$65^{1}$ Morpheus comes to sleeping Alcyone. $15^{8 \mathrm{v}}$

667 Ceyx and Alcyone stand next to sea; two birds fly overhead. $\quad 158 \mathrm{v}$

811 L'Amant places wreath on head of god of sleep (Morpheus), who sits sleeping on the bed.

Subsequent miniatures illustrate the meeting of the narrator and l'Amant, the fountain, the judgment of Paris, the appearance of the lady, and l'Amant's final departure by boat. 